\title{
THE USE OF TIE-INS IN NEW INDUSTRIES*
}

Bx conditioning the sale or lease of one product on the buyer's agreement to purchase or lease a second item, a seller can effectively limit or foreclose the access of competitors to the market for the second, or "tied" product. ${ }^{1}$ The tie-in utilizes the established demand for the "tying" product to coerce purchasers to buy the tied product. ${ }^{2}$ To effectuate a tie-in scheme, a seller must have substantial control over the supply of the tying device. ${ }^{3}$ These agreements are generally prohibited under the antitrust laws, ${ }^{4}$ and may be challenged by private parties, ${ }^{5}$ by the Attorney General, ${ }^{6}$ and by the Federal Trade Commission. ${ }^{7}$ On the presupposition that the vast majority of tie-ins are imposed for predominantly anticompetitive purposes, ${ }^{8}$ the Supreme Court has held that tying arrangements are illegal per se under the Sherman and Clayton Acts, ${ }^{9}$ provided that the seller

* United States v. Jerrold Electronics Corp., 187 F. Supp. 545 (E.D. Pa. 1960).

1. The tied item must be a second distinct commodity or service. If the two products are indistinguishable, no dominant "tying" product exists and no leverage in one market excludes sellers in the second because the products are identical and the market the same. Times-Picayune Publishing Co. v. United States, 345 U.S. 594, 614 (1953).

For general discussions of tying arrangements and their legal significance, see Bowman, Tying Arrangenents and the Leverage Problem, 67 YaLE L.J. 19 (1957); Turner, The Validity of Tying Arrangements Under the Antitrust Laws, 72 HaRv. L. Rev. 50 (1958); Note, Tying Restrictions: Changing Standards of Legality, 48 CoLUM. L. REv. 733 (1948); 56 MICH. L. Rev. 1214 (1958); 55 Coluar. L. Rev. 561 (1955).

2. Kaysen \& Turner, Antitrust Policy 154 (1959).

3. Control of supply may be acquired by patent monopoly or by other means. A competitive supplier, selling at the prevailing price and attempting to impose a tie-in upon the buyer, will normally be displaced by a seller who does not. But if the tyer has significant control of the supply of the tying product and may therefore impose a tie-in without fear of losing customers to any substantial degree, the tie-in will only slightly hinder distribution of the tying product. Bowman, supra note 1 , at 20.

4. Tying arrangements may be assailed as illegal restraints of trade under the Sherman Antitrust Act \& 1, 26 Stat. 209 (1890), as amended, 15 U.S.C. $\S 1$ (1958), or the Clayton Act $\$ 3,38$ Stat. 731 (1914), 15 U.S.C. $\$ 14$ (1958); as an unfair method of competition under the Federal Trade Commission Act $\$ 5,38$ Stat. 719 (1914), as amended, 15 U.S.C. \$ 45a (1958); or as an attempt to monopolize under the Sherman Antitrust Act § 2, 26 Stat. 209 (1890), as amended, 15 U.S.C. $\$ 2$ (1958).

5. Sherman Antitrust Act $\S \S 1-8,26$ Stat. 209 (1890), as amended, 15 U.S.C. $\S \S 1-7$ (1958) ; Clayton Act § 4, 38 Stat. 731 (1914), 15 U.S.C. § 15 (1958).

6. Sherman Antitrust Act $\S 4,26$ Stat. 209 (1890), as amended, 15 U.S.C. $\S 4$ (1958); Clayton Act $\S 15,38$ Stat. 736 (1914), as amended, 15 U.S.C. $\$ 25$ (1958).

7. Federal Trade Commission Act $\S 11,38$ Stat. 734 (1914), as amended, 15 U.S.C. § 21 (1958).

8. See Standard Oil Co. v. United States, 337 U.S. 293, 305 (1949).

9. Northern Pac. Ry. v. United States, 356 U.S. 1 (1958) (nonpatent tie-ins) ; Mercoid Corp. v. Minneapolis-Honeywell Regulator Co., 320 U.S. 680 (1944) (patent tie-in).

Other anticompetitive practices have been held illegal per se by the Supreme Court. United States v. Trenton Potteries Co., 273 U.S. 392 (1927) (price-fixing) ; Addyston Pipe \& Steel Co. v. United States, 175 U.S. 211 (1899) (apportioning markets); Fashion Originators' Guild of America v. FTC, 312 U.S. 457 (1941) (group boycotts). 
has "sufficient economic power to appreciably restrain free competition in the market for the tied product and if a 'not insubstantial' amount of interstate commerce is affected." 10 If a tying arrangement meets these prerequisites, "no genuine issue" remains, ${ }^{11}$ and other evidence relating to the "reasonableness" of the arrangement is irrelevant. ${ }^{12}$ The tying arrangement has already been proved to be a quantitatively undue limitation on competitive conditions.

In the usual case, only the desire to avoid competition would explain the seller's use of a tying arrangement. ${ }^{13}$ There may be other reasons, however. A tie-in may be employed as a means of assuring the satisfactory performance of a product. When a new creation or technological development is involved, satisfactory performance may be crucial to its survival-its ability to gain consumer recognition and acceptance. ${ }^{14}$ Such a "performance survival tie-in" may occur where company $X$ produces new creation $A$ and complementary product $B$, and: (1) only company $X$ sells $B$ s suitable to complement new product $A$; or (2) while other suitable $B$ s are sold by competitors, purchasers

10. Northern Pac. Ry. v. United States, supra note 9, at 6. Per se illegality under the Clayton Act attaches to the tying arrangement when the seller enjoys a monopolistic position in the market for the "tying" product or if a substantial volume of commerce in the "tied" product is restrained. Times-Picayune Publishing Co. v. United States, 345 U.S. 594, 606 (1953). However, the Clayton Act has been assumed not to apply to a lease, or sale, or contract, in terms applicable to "commodities," or sale of services. Northern Pac. Ry. v. United States, supra note 9, at 13 (dictum).

The separability of the two Northern Pacific criteria is questionable. The required finding of "monopoly power" or "dominance" has been interpreted to mean nothing more than a showing that the tyer has "sufficient economic power to impose an appreciable restraint on free competition in the tied product." Id. at 11. If the restraint described has occurred, the tyer must surely have had sufficient economic power to cause it. However, the Court continues to inquire into the "leverage" of the tyer, and has attached significance to the volume of tie-ins employed, the distinctiveness of the tying product, and the sales leadership of the tyer in the market for the tying product. Id. at 7, 8, 19.

11. International Salt Co. v. United States, 332 U.S. 392, 396 (1947) (motion for summary judgment granted).

12. Since United States v. Trans-Missouri Freight Ass'n, 166 U.S. 290, 328 (1897) was modified by Standard Oil Co. v. United States, 221 U.S. 1 (1911), the general rule has been that business conduct is illegal under the Sherman Act only if it constitutes an undue limitation on competitive conditions, or tends to create a monopoly. The quantitative test of undue restraint, however, has been conclusively presumed to be satisfied by the per se illegal practices. For a discussion of the rule of reason, see Adams, The "Rule of Reasonn," 63 Y ALE L.J. 348 (1954).

13. See Standard Oil Co. v. United States, 337 U.S. 293, 306 (1949).

The typical tying arrangement represents an economic exploitation of the demand curves facing the seller for his two products, $A$ and $B$. If the demand for product $A$ is less elastic than that for product $B$, he may be in a position to increase his total revenue through tying.

14. Of course, a tie-in may be used simply to guard the reputation of an established product, see Pick Mfg. Co. v. General Motors Corp., 80 F.2d 641 (7th Cir. 1935), aff'd, 299 U.S. 3 (1936) (tie-in of replacement parts to new car dealers only). In this case, however, the tie-in serves only to maintain a given level of sales; the market survival of the product (here, the automobile) does not seem to be at stake. See also FTC v. Sinclair Refining Co., 261 U.S. 463 (1923). 
buy unsuitable $B$ s because of their lower price or greater availability, despite warnings by company $X$ that they are inadequate. The performance tie-in thus serves to prevent functional failure of a new product by protecting the creation from consumer indiscretion. It conditions the sale of the new product on the purchase of a suitable complementary product, thereby protecting the tyer and his customer from avoidable substandard performance or total malfunctioning of the new product. ${ }^{15}$

The wisdom of applying the per se rule to performance survival tie-ins has been challenged by the recent district court decision in United States $v$. Jerrold Electronics Corp. ${ }^{16}$ a civil action brought by the Department of Justice to enjoin the defendant's use of tying arrangements. ${ }^{17}$ Jerrold, a young company, had developed the first successful community television antenna system capable of servicing communities in geographical areas where television signals could not effectively be received with conventional reception apparatus. None of the system equipment was covered by a valid patent. ${ }^{18}$ Jerrold's experience with its first customers had indicated that avoidable system failures were precipitated by improper installation and maintenance. To minimize servicing failures and foster the orderly growth of the new systems industry on which its future depended, Jerrold sold its equipment only on condition that the buyer agree to accept an installation and servicing contract as well. Moreover, since it could not render the services deemed necessary if its customers were permitted to purchase whatever components they desired, Jerrold adopted the policy of selling its equipment solely on a full-system basis. ${ }^{10}$ Between 1950 and 1955 , Jerrold had sold approximately $75 \%$ of the community television antenna systems in the country. ${ }^{20}$ The Government assailed both the

15. The Supreme Court has indicated that a tie-in imposed to protect a new product from functional failure may be upheld if suitable complementary products are unavailable. International Salt Co. v. United States, 332 U.S. 392, $397-98$ (1947) (dictum) ; cf. cases cited note 14 supra.

16. 187 F. Supp. 545 (E.D. Pa. 1960).

17. The Department of Justice relied upon $\S \S 1-2$ of the Sherman Act and $\S 3$ of the Clayton Act, but conceded that the Clayton Act had no application to the service contract tie-ins. $187 \mathrm{~F}$. Supp. at 554. The Government also challenged (1) a veto provision in Jerrold sales contracts requiring the company's approval of non-Jerrold equipment used in the new system, (2) a provision whereby purchasers must buy from Jerrold alone the equipment necessary to receive any stations in addition to those received at the time of the initial installation, (3) the acquisition by Jerrold of ten companies owning and operating community television systems, and (4) the use of Jerrold's methods patent to coerce purchasers to buy the Jerrold system. Of these the court held only the additional channels provision illegal. Id. at 561-71.

18. Id. at $555 \mathrm{n} .13$.

19. Id. at 560 . Unlike the service contract tie-in, the full system tie-in is subject to the provisions of $\S 3$ of the Clayton Act. Potential lessening of competition, requisite to illegality under $\$ 3$, can normally be inferred from the seller's dominant position in the market for the tying product. United Shoe Machinery Corp. v. United States, 258 U.S. 451, 457 (1922).

20. $187 \mathrm{~F}$. Supp. at 555 . The district court intimated that Jerrold's market share is now being challenged by competitors. Ibid. 
full system tie-in and the service contract tie-in as per se illegal under the ruling in Northern Pac. Ry. v. United States, the Supreme Court decision holding that a tie-in of nonpatented products is per se illegal ${ }^{21}$ under the Sherman Act if the tyer has sufficient economic power to appreciably restrain trade in the market for the tied product and if a not insubstantial amount of interstate commerce is affected. From an adverse judgment in the district court, Jerrold appealed to the Supreme Court which affirmed per curiam. ${ }^{21 a}$

The district court found that Jerrold's position in the community television system industry allowed it sufficient economic power to restrain trade in the market for services and system parts, and that the Northern Pacific test of per se illegality had been fully met. ${ }^{22}$ The court stated, however, that "any judicially, as opposed to legislatively, declared per se rule is not binding on this court as to any set of facts not basically the same as those in the case in which the rule was applied," 23 and distinguished Northern Pacific on its facts..24 The court set aside the per se rule because Jerrold's position and brief history in the new systems industry obviated the type of prolonged economic investigation that the per se rule is designed to avoid, ${ }^{25}$ and because of the "rather unique circumstances" of the case. ${ }^{26}$ Northern Pacific was thus held not to bar an inquiry into the "reasonableness" of Jerrold's tie-ins. The court then noted that the community television system industry might have been retarded or destroyed by the consumer reaction to a rash of early system failures. ${ }^{27}$ It also mentioned that Jerrold lacked the resources to survive initial setbacks, ${ }^{28}$ though it is not clear whether the court was concerned with the interests of Jerrold itself or simply the fact that Jerrold was the industry. Tie-ins were found necessary to prevent system failures on the ground that the intricacy of the new system and the training necessary for proper servicing made it impossible for Jerrold to prevent failures by supplying purchasers with instructions for installation and maintenance. ${ }^{29}$ Finding, in addition, that the full-system tie-in was a necessary adjunct to the service contract tie-in, the district court concluded that Jerrold's policy of selling its equipment solely on a full system basis and only in conjunction with a service contract violated no provision of the antitrust laws at its inception. ${ }^{30}$ It found, however, that, at the time of trial, the use of the tying arrangements was no longer necessary

21. 356 U.S. 1, 11 (1958).

21a. Jerrold Electronics Corp. v. United States (U.S., March 20, 1961).

22. 187 F. Supp. at 555 (services), 559 (system parts).

23. Id. at 556 .

24. Id. at 557.

25. Id. at 556 .

26. Id. at 555-56.

27. Id. at 557 .

28. Ibid.

29. Id. at 560 . The Supreme Court has held that a tie-in is unjustified if the legitimate purpose which it serves can be fulfilled by some means less destructive to competition. See, c.g., International Business Mach. Corp. v. United States, 298 U.S. 131, $138-39$ (1936).

30. $187 \mathrm{~F}$. Supp. at 571 . The court concluded that Jerrold's full system sales were, under the circumstances, sales of a "single product." Id. at 560 . 
for Jerrold's survival and therefore granted the government's prayer for an injunction. ${ }^{31}$

Essentially, the Jerrold decision held that the two conditions for the application of the Northern Pacific per se rule are met by performance survival tie-ins, but that an exception to that rule should be made in tying arrangement cases involving new industries with brief histories and readily ascertainable market characteristics. The decision suggests that application of the Northern Pacific rule is discretionary, and that a court may further inquire into the reasonableness of a tie-in whenever it finds that the rule's policy against prolonged and "fruitless" 32 economic investigation does not apply.

The court's emphasis on the new-industry characteristic of the case unnecessarily qualifies the Northern Pacific rule, which on its face leaves no discretion in the court to apply or reject it once the two conditions are satisfied..$^{33}$ The issue of discretion need never have been reached. A more thorough analysis of the prerequisites to application of the rule would have revealed that the rule is, by its own terms, inapplicable to every performance survival tie-in case. An essential prerequisite of per se illegality requires that the tie-in appreciably restrain trade in the relevant market for the tied product. ${ }^{34}$ An explicit finding of "appreciable restraint" seems necessary; no case has held that the restraint requirement will be satisfied by a finding of "dominance." 35 As defined by the Supreme Court, the relevant market in which restraint must be found includes "commodities reasonably interchangeable by consumers for the same purposes ...." Ass Ame that company $X$ produces new product $A$ and is the sole producer of a suitable complementary product, $B$. The "reasonable interchangeability" test would require the exclusion of competitors' unsuitable $B$ s from the determination of the relevant market for the tied product since an unsuitable $B$ is not a reasonable substitute. Thus, the per se rule, under its own test, would not apply to the performance survival tie-in imposed by company $X$. Indeed, since there are no other competitors in the $B$ market, there is no restraint of competition at all and thus no antitrust violation of any kind. ${ }^{37}$

31. Id. at $558,561,571$.

32. Northern Pac. Ry. v. United States, 356 U.S. 1, 5 (1958).

33. 356 U.S. at 5 .

34. Ibid.; Times-Picayune Publishing Co. v. United States, 345 U.S. 594, 606 (1953).

35. While the Supreme Court has seemed to say that "dominance" can be presumed from the fact of restraint, see note 10 supra, the converse presumption does not seem to have been adopted. It has held that evidence of dominance is relevant to a finding of potential lessening of competition under the Clayton Act. United Shoe Mach. Co. v. United States, 258 U.S. 451, 457-58 (1922). But it has not made potential lessening of competition a conclusive presumption arising from a finding of dominance. See, $\iota . g$., Standard Oil Co. v. United States, 337 U.S. 293, 306 (1949). And the appreciable restraint of trade requisite to illegality under either the Clayton or the Sherman Act must be shown actually to exist. Times-Picayune Publishing Co. v. United States, 345 U.S. 594, 606 (1953).

36. United States v. E. I. du Pont de Nemours \& Co., 351 U.S. 377, 395 (1956) ; see Times-Picayune Publishing Co. v. United States, supra note 35, at 612 n.31.

37. This analysis is equally applicable to a "commodity" tie-in under the Clayton Act because, while the cases permit courts to infer an appreciable restraint of competition in the 
The appreciable-restraint-of-trade prerequisite may still be unsatisfied even when, as in Jerrold, ${ }^{38}$ there are some competitors who produce adequate complementary products, i.e., when there is a competitive $B$ market. The key issue in such a situation would be whether customers will in fact purchase inadequate complementary products from other suppliers with sufficient frequency to undermine the reputation of product $A$ by the failures which they bring about.

Implicit in the test of appreciable restraint of trade is the requirement that the restraint of trade in the market for the tied product be appreciable in comparison to the market situation which would exist in the absence of the tying arrangement. ${ }^{30}$ But disallowance of a performance survival tie-in may force the manufacturer to abandon production of the new product, thereby eliminating entirely the market for complementary products used in conjunction with the new device. In comparison to this wholly adverse effect upon competition in complementary products, a temporary tie-in would not seem to "appreciably" restrain competition in the market for the tied product. ${ }^{40}$

By failing to recognize that the court's first problem was to define the relevant market-what the Supreme Court has called the predicate of every antitrust case ${ }^{41}$ - the Jerrold opinion threatens to lead to undesirable results if followed. It would permit a court to disregard the per se rule whenever, in its opinion, the circumstances of the case indicate that the economic inquiry would not be unduly burdensome or time-consuming. This approach not only adds a discretionary test of applicability inconsistent with the rule established by the Supreme Court, but also disregards the fundamental reason for the rule's existence. Tie-ins are so frequently imposed for no other reason than the elimination of competition that the Supreme Court has established what is in effect a nearly conclusive presumption of their illegality. ${ }^{42}$ Jerrold's purported exception to the rule fails to consider whether or not the pernicious anticompetitive effects are present. In contrast, the prerequisites established by the Supreme Court serve to exclude from the rule only those tie-ins which have little anticompetitive effect.

Other policies underlying the per se rule against tie-ins will not be offended by the allowance of performance survival tie-ins. In addition to preserving the

tied product from the existence of "dominance" over the tying product's market, see note 35 supra, such an inference of restraint would be erroneous here because, by hypothesis, the $B$ s provided by $X$ are not interchangeable with those of his rivals.

38. The district court related that other suppliers were selling presumably conventional amplifiers for use in the system. $187 \mathrm{~F}$. Supp. at 560-61.

- 39. See Times-Picayune Publishing Co. v. United States, 345 U.S. 594, 605 (1953).

40. Moreover, a reasonable inference of appreciable restraint under the Clayton Act cannot be made. See note 37 supra.

41. Times-Picayune Publishing Co. v. United States, 345 U.S. 594, 610-11 (1953).

42. Northern Pac. Ry. v. United States, 356 U.S. 1, 5 (1958). See also KronsteIn, Mitler \& Schwartz, Modern American Antitrust Law 82 (1958); New York Bar Ass'r, Antitrust Law Syarposiun 3-4 (1955). 
competitor's access to the market for the tied product, courts seek to protect buyer freedom. ${ }^{43}$ The vice of the tie-ins has been characterized as the use of "dominance" or "Ieverage" over one product to compel buyers to purchase another product from the same seller,"4 thereby depriving the purchaser of freedom to buy the new product only, or to buy both products from separate sources. The premise of this policy, however, is that the buyer will enjoy freedom to purchase in the absence of a tie-in, and this premise is unfounded in the case of the performance survival tie-in. In the first place, the buyer never has freedom not to purchase the tied part; by definition, a performance survival tie-in exists only when the tied part or service is essential to the functioning of the first or tying product. And while such tie-ins do seem to restrict the buyer's freedom of choice between suppliers of the tied part, this freedom too is illusory. It is unattainable for the same reason that a free competitive market in the tied product is unattainable. Were the per se rule interposed to disallow the tie-in, the producer would be forced to abandon the new creation or technological development, and the buyer would be deprived of both products whose purchase the policy against tie-ins was intended to facilitate. ${ }^{45}$ Far from harming the buyer, a performance survival tie-in might be viewed as a means of protecting his investment in the new product, for it minimizes the risk of avoidable and possibly dangerous functional failures. ${ }^{46}$ In so far as the law has consistently discouraged marketing of defective and inferior goods, ${ }^{47}$ public policy would seem to favor such tie-ins as a means of restraining suppliers of defective parts and services. ${ }^{48}$

The positive benefits conferred by a performance survival tie-in also argue for its allowance. Since the main use of such tie-ins would be to make it possible for innovators to introduce new products into the economy, their allowance would seem a proper corollary to the patent law of encouraging innovation. ${ }^{50}$ At the same time, the performance survival tie-in would not constitute an extension of patent-like protection to nonpatented innovations. While exclusive control is given for a temporary period, it does not represent limitation

43. See Times-Picayune Publishing Co. v. United States, 345 U.S. 594, 605 (1953).

44. See Turner, supra note 1 , at 60 .

45. See text at notes $38-40$ supra.

46. In the Jerrold case, for example, improper installation of the antenna system would at least have made it function improperly. $187 \mathrm{~F}$. Supp. at 556-57; in addition, the misuse of various electronic devices might have caused actual injury to the equipment or to the persons working with it.

47. See Miller, Manufacturers' Product Liability Re-Visited, 23 INs. Counser J. 175 (1956) ; cf. Tampa Drug Co. v. Wait, 103 So. 2d 603 (1958).

48. This policy might be considered inapplicable where the defect guarded against by the tie-in is defective customer installation or home repair.

49. Northern Pac. Ry. v. United States, 356 U.S. 1, 5, 8 (1958). See also the discussion in the instant case, $187 \mathrm{~F}$. Supp. at 555.

50. See generally Frost, The Patent System and the Modern Economy, Study No. 2 of the Subcommittee on Patents, Trademarks, and Copyrights of the Senate Committee on the Judiciary, pursuant to S. 167, 84th Cong., 2d Sess., at 1-19 (1957). 
on competition for an arbitrary period; control can be enjoyed only so long as the alternative to control would be the destruction of the market altogether. ${ }^{51}$

Some statements in the Jerrold opinion suggest that youth and smallness of the defendant may have been an additional reason for declaring the initial use of the tie-in legal. ${ }^{52}$ While the size of the business involved is not relevant to performance survival tie-in justification, it may furnish an additional ground for decision in the instant case. Debates in the Senate prior to the passage of the Clayton Act indicate that flexibility was intended in the application of the act to the newcomer or the small business enterprise, and that tying arrangements imposed by the "little struggling institution" should be treated specially if the tyer cannot effectively compete with established interests without them. ${ }^{53}$ Dictum in the Standard Stations case suggests that exclusive dealing contracts employed for the purpose of establishing a foothold against the counter-attacks of entrenched competitors may be exempted from the per se rule. ${ }^{54}$ The Jerrold court found that the tying arrangement was essential to Jerrold's survival in the industry. ${ }^{55}$ Assuming that RCA or Philco because of their size and capital resources could have developed the community television antenna industry without the help of the tie-in, prohibiting Jerrold's use of tie-ins would have the effect of excluding a small business from developing this new industry. This result is similar to that noted in Standard Stations where the inability to use restrictive contracts would have excluded small business from the retail gasoline market. If the purpose of congressional and judicial policy is to assure the ability of small businesses to compete with their big brothers, this policy should be applied to new as well as established markets.

51. Compare the discussion of a patentee's monopoly over component parts of a combination patent in Note, 70 YaLE L.J. 649, 654 (1961).

52. See $187 \mathrm{~F}$. Supp. at $\mathbf{5 5 7}$ (failures would have "greatly retarded, if not destroyed, this new industry and would have been disastrous for Jerrold, who, unlike . . R.C.A. and Philco, did not have a diversified business to fall back on").

53. 51 Cong. Rec. 14094 (1914), discussed in Dictograph Prods., Inc. v. FTC, 217 F.2d 821, 827 (2d Cir. 1954).

54. Standard Oil Co. v. United States, 337 U.S. 293, 307 (1949).

55. $187 \mathrm{~F}$. Supp. at 557, quoted note 52 supra. 